\title{
A new stenopodid shrimp of the genus Odontozona Holthuis, 1946 (Crustacea: Decapoda: Stenopodidea) from Taiwan
}

\section{Новая стеноподидная креветка рода Odontozona Holthuis, 1946 (Crustacea: Decapoda: Stenopodidea) с Тайваня}

\author{
Chien-Lin Chen ${ }^{1}$, Tin-Yam Chan ${ }^{1,2}$ \\ Чиен-Аинь Чен ${ }^{1}$, Тин-ЯМ Чан ${ }^{1,2}$
}

\footnotetext{
${ }^{1}$ Institute of Marine Biology, National Taiwan Ocean University, Keelung 20224, Taiwan. E-mail: reginald@mail.ntou.edu.tw

${ }^{2}$ Center of Excellence for the Oceans, National Taiwan Ocean University, Keelung 20224, Taiwan. E-mail: tychan@mail.ntou.edu.tw

${ }^{2}$ Corresponding author
}

KEY WORDS: taxonomy, Stenopodidae, new genus, new record.

КЛЮЧЕВЫЕ СЛОВА: таксономия, Stenopodidae, новый род, новая находка.

ABSTRACT. The stenopodidean shrimp genus $\mathrm{Od}$ ontozona Holthuis, 1946 is recorded from Taiwan for the first time with a new species $O$. spiridonovi sp.n. The new species is unique in the genus Odontozona by the propodus of the third pereiopod being swollen; more than twice the width of the carpus, and with the dorsal and ventral margins densely serrated. The new species is most similar to O. stigmatica Saito, Okuno et Anker, 2017 but differs in the armature on the ventral margin of the rostrum, the third maxilliped and the palm of the third pereiopod, as well as its coloration.

How to cite this paper: Chen Ch.-L., Chan T.-Y. 2021. A new stenopodid shrimp of the genus Odontozona Holthuis, 1946 (Crustacea: Decapoda: Stenopodidea) from Taiwan // Arthropoda Selecta. Vol.30. No.3. P.299-308. doi: 10.15298/arthsel. 30.3.04

РЕЗЮМЕ. Род стеноподидных креветок Odontozona Holthuis, 1946 впервые зарегистрирован на Тайване с описанием нового вида $O$. spiridonovi sp.n. Новый вид уникален в роде Odontozona вздутым проподусом третьих переопод, который более чем в два раза превышает ширину запястья, а дорсальные и брюшные края густо зазубрены. Новый вид наиболее похож на O. stigmatica Saito, Okuno et Anker, 2017, но отличается вооружением нижнего края рострума, третьих максиллипед и ладони (клешни) третьего переопода, а также окраской.

\section{Introduction}

The stenopodid shrimp genus Odontozona Holthuis, 1946 is the most specious genus amongst stenopodid shrimps with 21 species known [De Grave, Fransen, 2011; Goy, 2015; Criales, Lemaitre, 2017; Saito et al., 2017; Saito, Fujita, 2018]. These small-sized shrimps occur in different world oceans and are distributed from shallow waters to very deep sea (Table
1). Although nine species of Odonozona have been reported in the Indo-West Pacific, none has been recorded from Taiwan. During recent experimental trawling off Taiwan, a specimen of Odonozona was collected off the southwestern coast at about $150 \mathrm{~m}$ depth. Detailed examination of this specimen revealed that this specimen does not only represent the first record of the genus from Taiwan, it is also a species new to science.

The holotype is deposited in the National Taiwan Ocean University, Keelung (NTOU). The abbreviation of CP indicating the type of collecting gear, $4 \mathrm{~m}$ French beam trawl. The measurement given is carapace length (cl) measured dorsally from the postorbital margin to the posterior margin. Morphological terminology mainly follows Goy [2010] and Saito et al. [2017].

\section{Taxonomy}

Family STENOPODIDAE Claus, 1872 Genus Odontozona Holthuis, 1946

\section{Odontozona spiridonovi sp.n.} Figs $1-6$.

MATERIAL EXAMINED. Holotype, ơ, cl $5.3 \mathrm{~mm}$ (NTOU M02298), Taiwan, TAIWAN 2020, stn. CP4210, $22^{\circ} 18.941^{\prime} \mathrm{N}$, $120^{\circ} 20.570^{\prime} \mathrm{E}, 116-159 \mathrm{~m}, 14.11 .2020$.

DIAGNOSIS. Small-sized shrimp with laterally compressed body. Rostrum straight, directed forwards, with 7 dorsal, 3 ventral teeth. Carapace with cervical groove, armed with cincture of spines along posterior margin; hepatic and antennal spines acute. Posterolateral surface of carapace with 2-3 spinules on each side. Cornea darkly pigmented. Abdomen without sculpture, first and second pleura with transverse carina, sixth pleuron devoid of lateral spines and with sharp ventral angle. Scaphocerite bearing 5 lateral teeth. Palm of third pereiopod swollen and more than twice as broad as carpus, with both dorsal and ventral margins densely serrated. Fourth and fifth pereiopods with propodi subdi- 
Table 1. Geographical and bathymetric ranges of the species of the genus Odontozona Holthuis, 1946. Таблица 1. Географические и батиметрические ареалы видов рода Odontozona Holthuis, 1946.

\begin{tabular}{|c|c|c|c|}
\hline Species & Geographical Range & Depth & References \\
\hline Odontozona addaia Pretus, 1990 & Mediterranean & $5-20 \mathrm{~m}$ & $\begin{array}{l}\text { Pretus, 1990; Chevaldonné, } \\
\text { Pretus.2021 }\end{array}$ \\
\hline $\begin{array}{l}\text { Odontozona anaphorae Manning et } \\
\text { Chace, } 1990\end{array}$ & Central Atlantic & $10-30 \mathrm{~m}$ & $\begin{array}{l}\text { Manning, Chace, } 1990 \\
\text { Herrera et al., } 2016\end{array}$ \\
\hline $\begin{array}{l}\text { Odontozona arbur Saito, Okuno et } \\
\text { Anker, } 2017\end{array}$ & Indo-West Pacific & $0.5-36 \mathrm{~m}$ & Saito et al., 2017; Lee, 2020 \\
\hline $\begin{array}{l}\text { Odontozona crinoidicola Saito et } \\
\text { Fujita, } 2009\end{array}$ & Indo-West Pacific & $3.2-7 \mathrm{~m}$ & $\begin{array}{l}\text { Saito, Fujita, 2009; Saito et } \\
\text { al., } 2017\end{array}$ \\
\hline Odontozona edwardsi (Bouvier, 1908) & East Atlantic & $511-2070 \mathrm{~m}$ & $\begin{array}{l}\text { Bouvier, 1908; Goy, } \\
\text { Cardoso, } 2014\end{array}$ \\
\hline Odontozona ensifera (Dana, 1852) & Indo-West Pacific & $2-440 \mathrm{~m}$ & $\begin{array}{l}\text { Dana, 1852; Goy, 1981, } \\
2015\end{array}$ \\
\hline $\begin{array}{l}\text { Odontozona edyli Criales et Lemaitre, } \\
2017\end{array}$ & Indo-West Pacific & $12 \mathrm{~m}$ & Criales, Lemaitre, 2017 \\
\hline Odontozona fasciata Okuno, 2003 & Indo-West Pacific & $6-45 \mathrm{~m}$ & $\begin{array}{l}\text { Okuno, 2003; Goy, } 2015 \\
\text { Hendrickx, 2002; }\end{array}$ \\
\hline Odontozona foresti Hendrickx, 2002 & East Pacific & $1058-1270 \mathrm{~m}$ & $\begin{array}{l}\text { Hendrickx, Ayon-Parente, } \\
2014\end{array}$ \\
\hline $\begin{array}{l}\text { Odontozona joegoyi Hendrickx et } \\
\text { Ayon-Parente, } 2014\end{array}$ & East Pacific & $750-850 \mathrm{~m}$ & $\begin{array}{l}\text { Hendrickx, Ayon-Parente, } \\
2014\end{array}$ \\
\hline Odontozona libertae Gore, 1981 & West Atlantic & $7-56 \mathrm{~m}$ & $\begin{array}{l}\text { Gore, 1981; Criales, 1997; } \\
\text { De Grave, Anker, } 2017\end{array}$ \\
\hline $\begin{array}{l}\text { Odontozona lopheliae Goy et } \\
\text { Cardoso, } 2014\end{array}$ & West Atlantic & $459-665 \mathrm{~m}$ & Goy, Cardoso, 2014 \\
\hline $\begin{array}{l}\text { Odontozona meloi Anker et Tavares, } \\
2013\end{array}$ & West Atlantic & $81.6 \mathrm{~m}$ & Anker, Tavares, 2013 \\
\hline $\begin{array}{l}\text { Odontozona minoica Dounas et } \\
\text { Koukouras, } 1989\end{array}$ & Mediterranean & $125-330 \mathrm{~m}$ & $\begin{array}{l}\text { Dounas, Koukouras, } 1989 ; \\
\text { Koukouras, Dounas, } 2000\end{array}$ \\
\hline $\begin{array}{l}\text { Odontozona okunoi Saito et Fujita, } \\
2018\end{array}$ & Indo-West Pacific & $13-15 \mathrm{~m}$ & Saito, Fujita, 2018 \\
\hline Odontozona rubra Wicksten, 1982 & East Pacific & $5-10 \mathrm{~m}$ & Wicksten, 1982; Goy, 1992 \\
\hline $\begin{array}{l}\text { Odontozona sculpticaudata Holthuis, } \\
1946\end{array}$ & Indo-West Pacific & $0.5-70 \mathrm{~m}$ & $\begin{array}{l}\text { Holthuis, 1946; Goy, 2015; } \\
\text { Saito et al., } 2017\end{array}$ \\
\hline $\begin{array}{l}\text { Odontozona spinosissima Kensley, } \\
1981\end{array}$ & Indo-West Pacific & $200 \mathrm{~m}$ & Kensley, 1981 \\
\hline Odontozona spiridonovi sp.n. & Indo-West Pacific & $116-159 \mathrm{~m}$ & Present study \\
\hline $\begin{array}{l}\text { Odontozona spongicola (Alcock et } \\
\text { Anderson, 1899) }\end{array}$ & Indo-Pacific & $392-900 \mathrm{~m}$ & $\begin{array}{l}\text { Alcock, Anderson, 1899; } \\
\text { Alcock, 1901; Goy, 1992; } \\
\text { Chen, Chan, } 2021\end{array}$ \\
\hline $\begin{array}{l}\text { Odontozona stigmatica Saito, Okuno } \\
\text { et Anker, } 2017\end{array}$ & Indo-West Pacific & $5 \mathrm{~m}$ & Saito et al., 2017 \\
\hline Odontozona striata Goy, 1981 & West Atlantic & $238-730 \mathrm{~m}$ & Goy, 1981; Okuno, 2003 \\
\hline
\end{tabular}

vided into 4 articles, each with 22-27 movable spinules on ventral margin, carpi subdivided into 5-6 articles. Telson lance-shaped, dorsal surface with dorsolateral carinae bearing 3 strong spines; posterior margin with 2 posterolateral spines; lateral margin with shallow subproximal concavity and 1 distinct medial spine. Outer margin of uropodal endopod with 2 spines, dorsal surface with an intermediate spine and 1 longitudinal carina; outer margin of uropodal exopod with 6 spines, dorsal surface unarmed but with 2 longitudinal carinae.

DESCRIPTION. Small-sized shrimp with laterally compressed body. Rostrum (Figs 2, 4A, B) 0.37 times carapace length, compressed, straight, directed forward, reaching dis- tal margin of third segment of antennular peduncle; dorsal margin armed with 7 teeth, proximal most tooth situated at level of postorbital margin; ventral margin armed with 3 teeth on anterior half; lateral ridge moderately developed, unarmed.

Carapace (Figs 2, 4A, B) rounded on posterolateral margin. Mid-dorsal carina moderately developed in anterior part of carapace. Orbital margin concave, inferior orbital angle rounded. Antennal lobe rounded. Acute antennal and hepatic spines present. Pterygostomial angle slightly rounded, not exceeding antennal lobe, armed with 3 large pterygostomial spines. Cervical groove prominent, posterior margin with cincture of 13 spinules, medial spinules similar in size as 


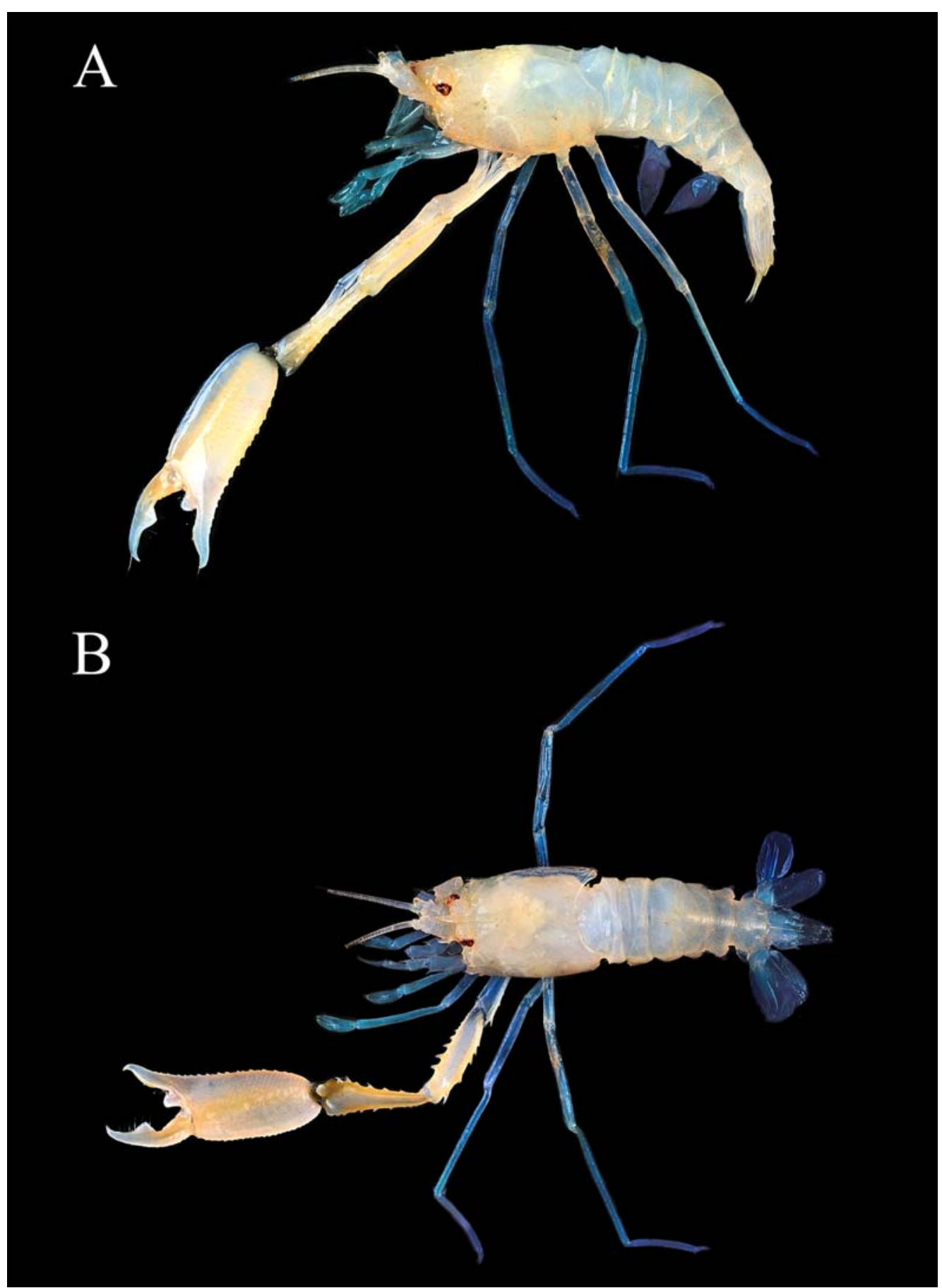

Fig. 1. Odontozona spiridonovi sp.n., Taiwan, holotype, ơ , cl $5.3 \mathrm{~mm}$ (NTOU M02298), right second, third and fifth pereiopods missing. A - lateral view; B - dorsal view.

Рис. 1. Odontozona spiridonovi sp.n., Тайвань, голотип, O7, cl 5,3 мм (NTOU M02298), правые 2-й, 3-й и 5-й переопод отсутствуют. А — вид сбоку; В — вид сверху.

lateral spinules. Supraorbital region bearing 2 spines. Posterolateral parts of carapace with 2-3 spinules on each side.

Eyes (Figs 2, 4A, B) well developed. Cornea shorter and narrower than peduncle, hemispherical, darkly pigmented. Mesial surfaces of eyestalks armed with many spinules.

Antennular peduncle (Figs 2, 4A, B) exceeding base of scaphocerite. First (basal) segment longest, slightly longer than second segment. Stylocerite moderately large, acute, curved inwards. Second segment with 1 large dorsal and 1 lateral spines. Third segment as long as second segment, unarmed. Flagella slender.

Antennal basicerite robust (Figs 2, 4A, B), with dorsolateral and ventrolateral spines. Scaphocerite semicircular in form, about 2 times longer than broad, bearing 5 teeth on 


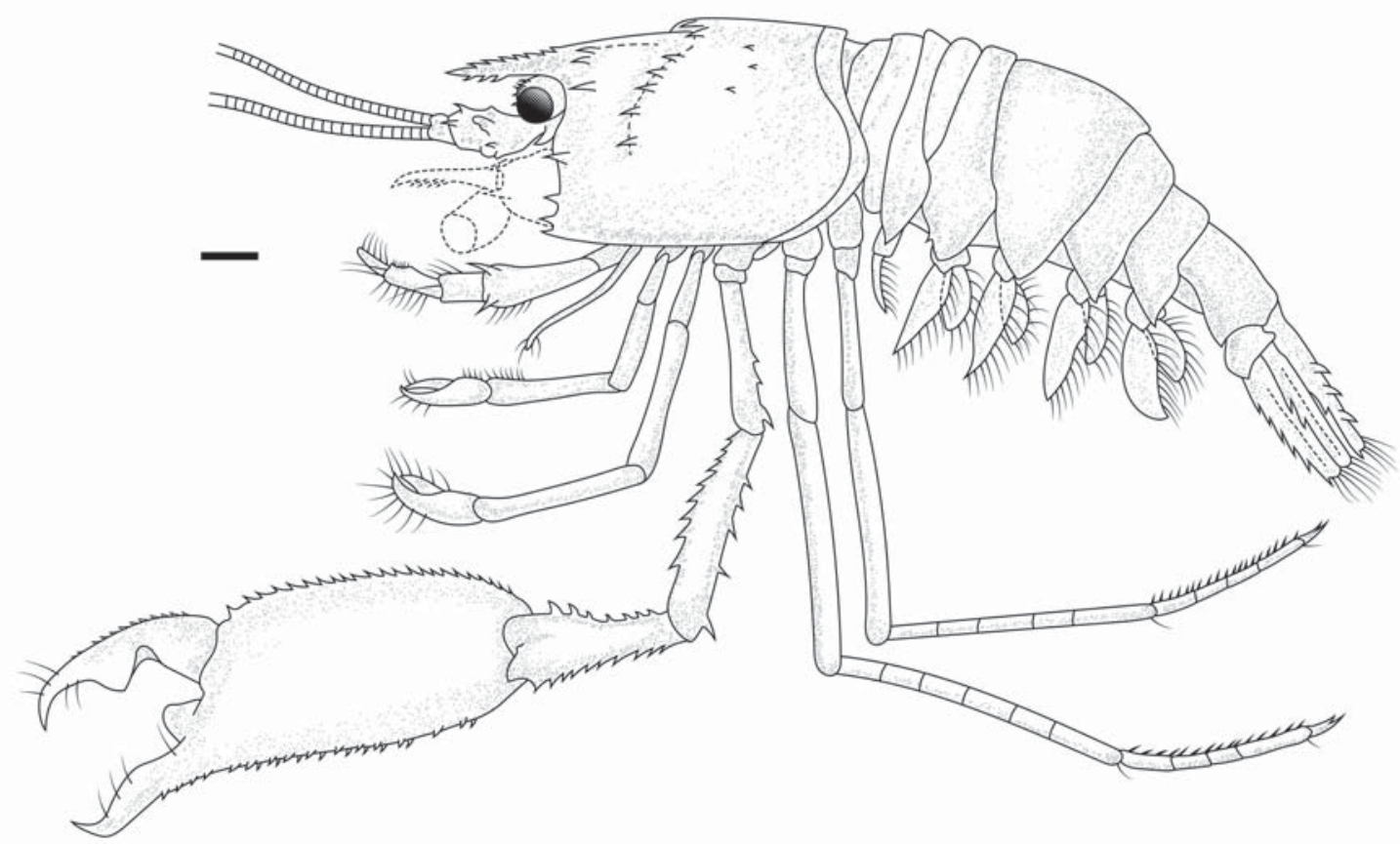

Fig. 2. Odontozona spiridonovi sp.n., Taiwan, holotype, ơ', cl $5.3 \mathrm{~mm}$ (NTOU M02298), lateral view. Scale bar: $1 \mathrm{~mm}$. Рис. 2. Odontozona spiridonovi sp.n., Тайвань, голотип, о7, cl 5,3 мм (NTOU M02298), вид сбоку. Масштаб 1 мм.

lateral margin, terminal tooth overreaching distal margin of lamella; dorsal surface with 2 longitudinal carinae fused at base; mesial margin strongly convex. Carpocerite cylindrical, reaching about midlength of antennal scale.

Epistome (Fig. 3A) anteriorly with 2 sharp, slightly curved lateral spines. Labrum rhombic, anterior and posterior margins strongly convex.

Mandible (Fig. 3B) stout, with robust palm composed of 3 articles. Distal segment oval but slightly pointed at tip, densely setose. Intermediate segment stout, decreasing in size posteriorly. Basal segment as long as median segment, increasing in size proximally. Incisor and molar processes not fully separate, margin of incisor with 2 large acute and 1 small stout teeth, margin of molar armed with 2 large acute teeth.

Maxillule (Fig. 3C, D) robust. Endopod slender and tapering distally. Coxal endite broad, with row of setae on distal margin. Basial endite moderately rectangular, truncated distally, with row of 13 slender subequal spines.

Maxilla (Fig. 3E) with sturdy, robust endopod. Coxal endite suboval. Basial endite oblong. Both coxal and basial endites distinctly bilobed. Scaphognathite well developed; anterior lobe rather large and rectangular, with dense long setae along anterior and inner margins; posterior lobe subquadrate and slightly truncated distally, inner and posterior margins with rows of setae. ble 2 .

Gills trichobranchiate, branchial formula shown in Ta-

First maxilliped (Fig. 3F) with stout endopod consisting of 2 articles. Distal article tapering with long setae along outer margin. Proximal article subquadrate, with long setae on outer margin and basal inner margin. Coxal endites distinctly bilobed. Basial endite subtriangular, inner margin rounded and concave. Exopod well developed, robust and long. Epipod moderately large and distinctly bilobed, anteri- or lobe rectangular, posterior lobe rather triangular, both margins of anterior and posterior lobes somewhat sinuously.

Second maxilliped (Fig. 3G) with robust 4-jointed endopod. Dactylus suboval, with dense fringe of setae along dorsal margin. Propodus short, less than half of dactylus in length, with dense cover of setae on dorsal margin. Carpus short, cup-like, with long setae on dorsal margin. Merus most robust, slightly longer than dactylus, dorsal margin straight, ventral margin convex and serrated, with long setae. Ischium, basis and coxa fused. Exopod moderately long, distally with long setae. Podobranches well developed. Epipod oval in shape.

Third maxilliped (Figs 2, 5A) pediform, setose. Dactylus 0.6 times as long as propodus, with 9 long setae on ventral margin. Propodus with distinct setiferous organs at distomesial angle, bearing numerous long setae on distal and dorsal margins. Carpus slightly longer than propodus and with dense long setae on ventral margin. Merus longest, about 2 times as long as propodus, somewhat widened distally, armed with single prominent submarginal spine at both dorsolateral and ventraolateral distal angles. Ischium about 0.4 times as long as merus. Exopod reaching distal margin of endopodal merus, bearing several setae distally.

First 3 pereiopods chelate, greatly increasing in size posteriorly. First pereiopod (Figs. 2, 5B) slender, thin, overreaching scaphocerite by length of chela, with well-developed grooming apparatus; fingers about as long as palm, curved, leaving distinct hiatus, bearing tufts of long setae distally; carpus longest, 1.3 times as long as chela, cylindrical and slightly widened distally; merus 0.7 times length of carpus; ischium 0.6 times length of merus.

Second pereiopod (Figs 2, 5C) similar to first pereiopod, but longer (1.4 times) and lacking grooming apparatus. Dactylus 0.5 time length of propodus. Chela with outer margins convex, bearing numerous long setae in anterior part, cut- 
A

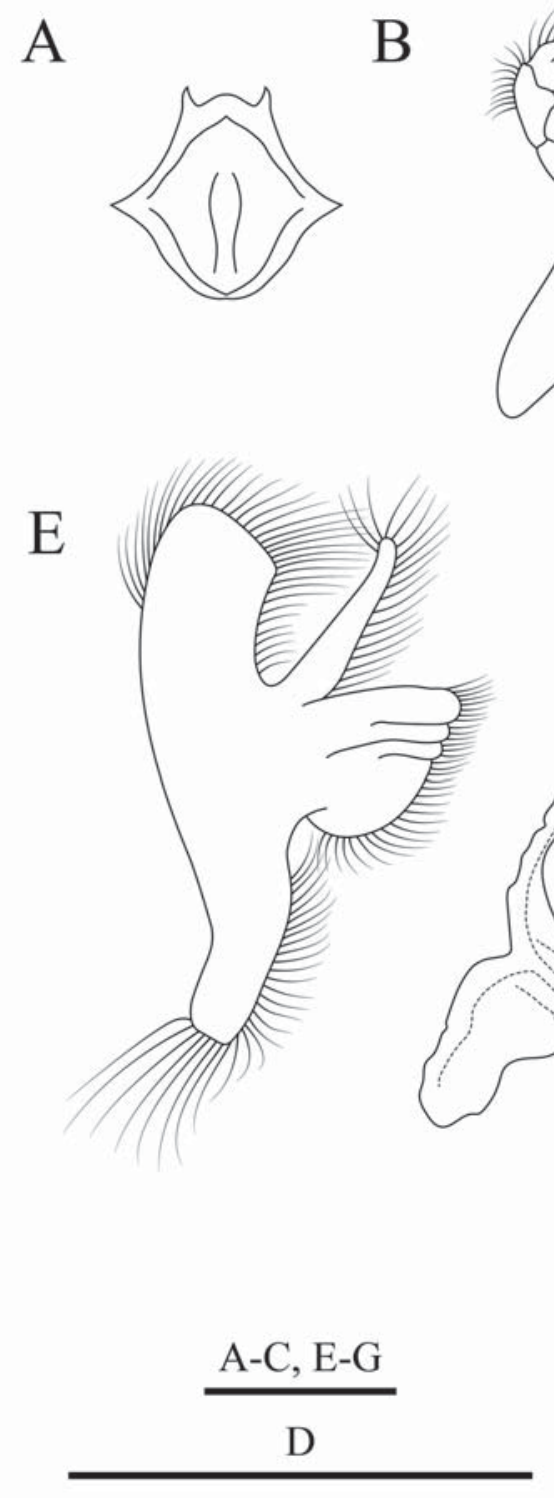

B

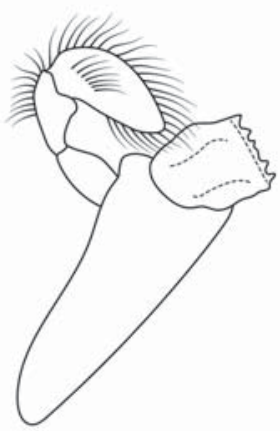

C

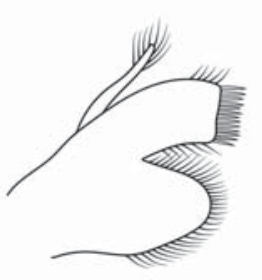

D

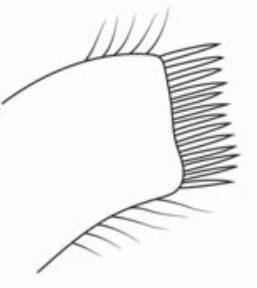

F

G
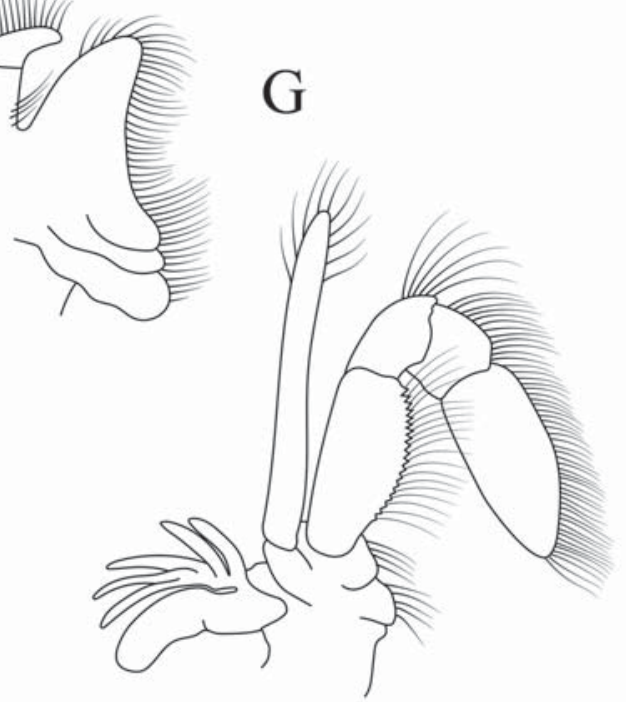

Fig. 3. Odontozona spiridonovi sp.n., Taiwan, holotype, or, cl $5.3 \mathrm{~mm}$ (NTOU M02298). A — epistome and labrum, ventral view; B right mandible, ventral view; $\mathrm{C}$ - right maxillula, ventral view; D — basial endite of right maxillula, ventral view; E — right maxilla, ventral view; F — right first maxilliped, ventral view; G - right second maxilliped, ventral view. Scale bars: $1 \mathrm{~mm}$.

Рис. 3. Odontozona spiridonovi sp.n., Тайвань, голотип, о, cl 5,3 мм (NTOU M02298). А - эпистома и нижняя губа, вид снизу; В - правая мандибула, вид снизу; C - правая максиллула, вид снизу; D — базальный эндит 1-й максиллулы, вид снизу; Е правая максилла, вид снизу; F — правая 1-я максиллипеда, вид снизу; G - правая 2-я максиллиипеда, вид снизу. Масштаб 1 мм.

ting edges of fingers bearing submarginal row of short setae. Carpus longest, 1.8 times as long as chela. Merus 0.9 times length of carpus. Ischium 0.5 times meral length.

Third pereiopod (Figs 2, 5D, E) robust, extending beyond scaphocerite by half length of merus. Fingers slightly compressed, noticeably curved distally, crossed when closed, terminating in acute tips. Movable finger (dactylus) 0.4 times chela length; extensor margin strongly convex, bearing tufts of long setae distally, dorsomesial margin serrated with 12 spinules; cutting edge crested, with prominent triangular tooth near midlength, proximal part forming deep concavity accommodating tooth on fixed finger. Fixed finger with cutting edge sinuous, also crested, proximal portion with 1 large blunt tooth, concavity in middle part opposing to dactylar tooth. Propodus distinctly swollen, more than twice as broad as carpus; lateral and mesial surfaces glabrous, gently convex; dorsal margin slightly convex and feebly carinate, armed with 23 distally directed spines, spines at proximal part smaller and more closely spaced, distal most and second spines furthest apart; ventral margin also gently convex, bearing 2 rows of 15 distally directed spines in each row but not in pairs. Carpus about half length of chela, dorsal margin with 7 acuminate, distally directed spines, decreasing in size proximally, ventral margin bearing10 acute subequal spines. 

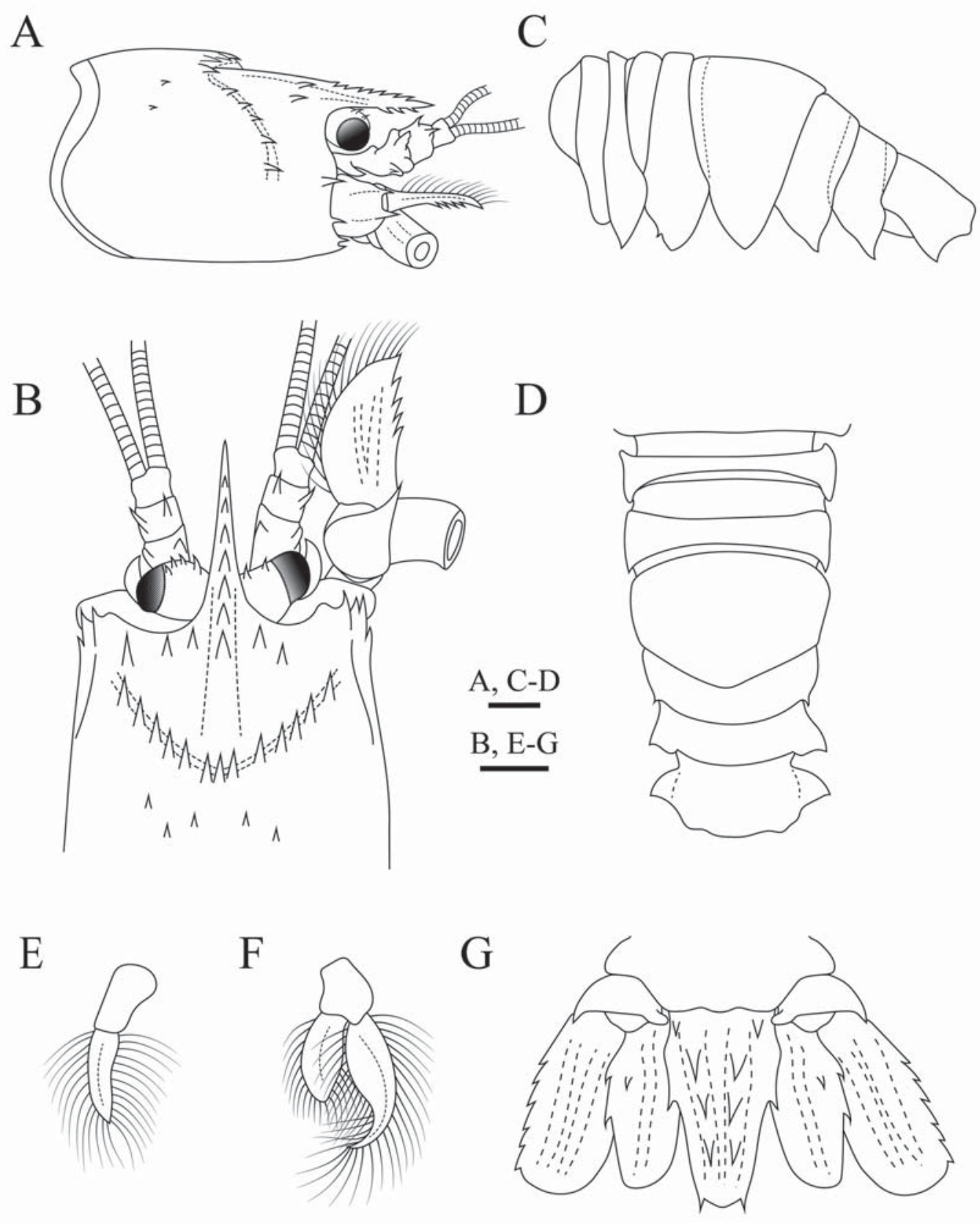

Fig. 4. Odontozona spiridonovi sp.n., Taiwan, holotype, $\sigma^{\top}$, cl $5.3 \mathrm{~mm}$ (NTOU M02298). A — right carapace and cephalic appendages, lateral view; B — anterior carapace and cephalic appendages, dorsal view (left antenna missing); C — left abdominal somites, lateral view; D - abdominal somites, dorsal view; E, — left first pleopod, lateral view; F — right fifth pleopod, lateral view; $\mathrm{G}$ - telson and uropods, dorsal view (setae omitted). Scale bars: $1 \mathrm{~mm}$.

Рис. 4. Odontozona spiridonovi sp.n., Тайвань, голотип, О7, cl 5,3 мм (NTOU M02298). А — карапакс и ротовые придатки, справа, вид сбоку; В - передняя часть карапакса и ротовые придатки, вид сверху (левая антенна отсутствует); С - левые брюшные (абдоминальные) сомиты, вид сбоку; D - брюшные (абдоминальные) сомиты, вид сверху; Е — левый 1-й плеопод, вид сбоку; F - правый 5-й плеопод, вид сбоку; G — тельсон и уроподы, вид сверху (щетинки удалены). Масштаб 1 мм.

Merus as long as carpus, with 9 dorsal spines increasing in size distally, ventral margin with 5 spines. Ischium 0.8 times length of merus, with 3 ventral spines, distal spine largest and elongated.

Fourth and fifth pereiopods (Fig. 6A-D) moderately slender and similar, both overreaching scaphocerite by carpus to dactylus. Dactyli distinctly biunguiculate, 0.2 times length of propodus. Propodus 0.6 times carpal length, subdivided into 4 articles, flexor margin with row of 25-28 movable spinules. Carpus subdivided into 5-6 articles, sometimes with 1 stiff seta at dorsodistal angle. Merus 0.8 times carpal length. Ischium 0.6 times length of merus, unarmed.

Sixth thoracic sternite (Fig. 6E) with pair of thin, rectangular plates jointed medially; anterolateral angle blunt but elon- 


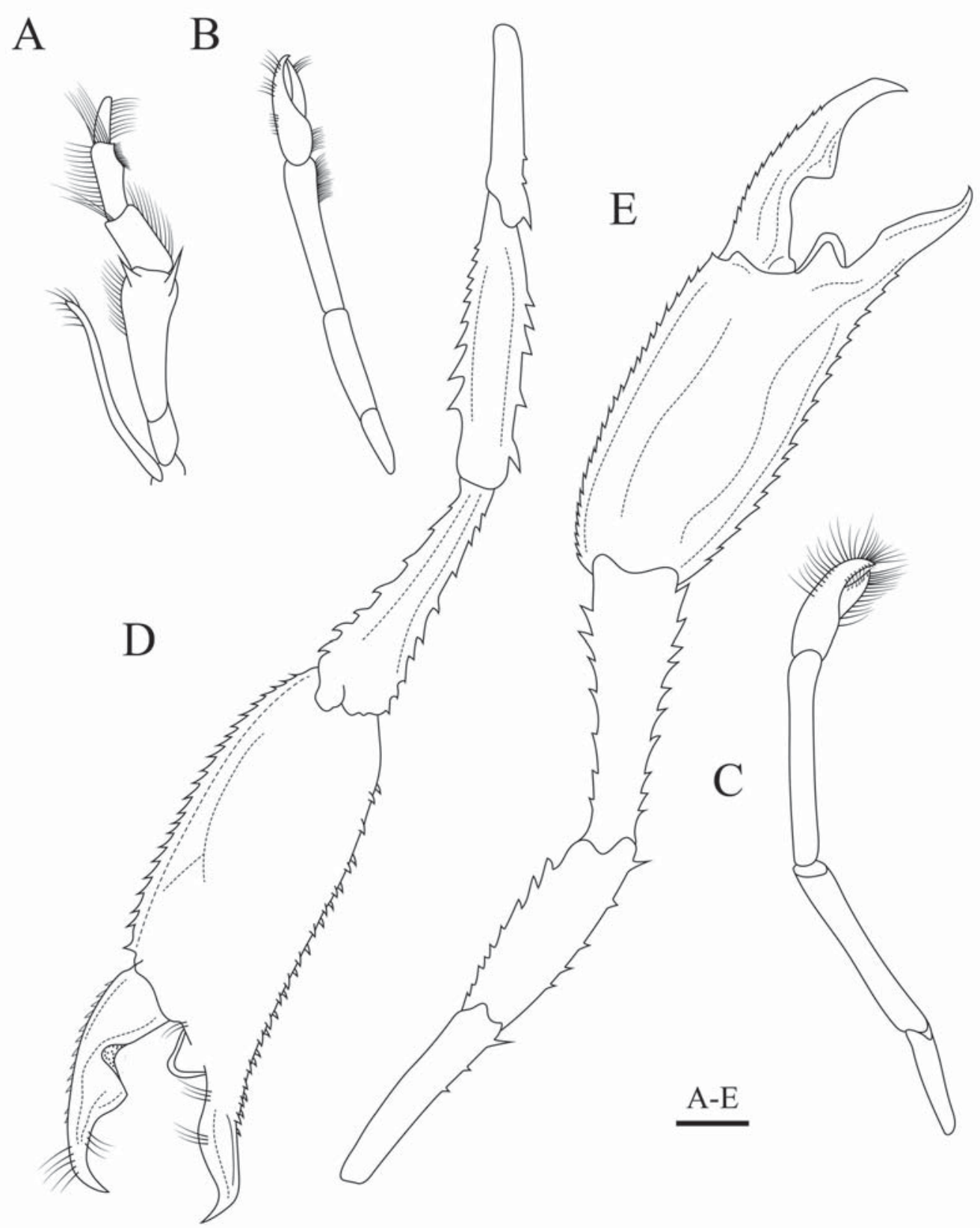

Fig. 5. Odontozona spiridonovi sp.n., Taiwan, holotype, $0^{7}$, cl $5.3 \mathrm{~mm}$ (NTOU M02298). A — left third maxilliped, lateral view; B left first pereiopod, lateral view; C - left second pereiopod, lateral view; D - left third pereiopod, lateral view; E — left third pereiopod, mesial view. Scale bar: $1 \mathrm{~mm}$.

Рис. 5. Odontozona spiridonovi sp.n., Тайвань, голотип, О, cl 5,3 мм (NTOU M02298). А - левая 3-я максиллипеда, вид сбоку; В - левая 1-я переопода, вид сбоку; С - левая 2-я переопода, вид сбоку; D - левая 3-я переопода, вид сбоку; Е - левая 3-я переопода, мезиальный вид. Масштаб 1 мм.

gated; lateral margin concave; anteromesial margin unarmed; ventral surface concave, unarmed. Seventh thoracic sternite with pair of broad rectangular plates, anterolateral angle stout, lateral margin somewhat sinuous, anteromesial margin concave and smooth, ventral surface concave. Eight thoracic sternite with pair of trapezoid plates, distolateral angle sharp, lateral margin deeply concave at anterior part, anteromesial margin sinuous, ventral surface concave and unarmed.

Abdomen (Figs 2, 4C, D) glabrous, without sculpture except for single transverse carina on first and second somites. First pleuron unarmed and with anterior part ventrally rounded while posterior part sharply produced ventrally. Second pleuron bluntly pointed ventrally and bearing 1 spinule on anterior margin. Third somite largest, posterodorsal margin moderately produced posteriorly, pleuron unarmed and bluntly pointed. Fourth and fifth pleura unarmed but each strongly produced ventrally and terminating in acute tip. Sixth somite unarmed except for pleuron terminating ventrally into acute angle. First pleopod (Fig. 4E) uniramous, shorter than other pleopods. Second 


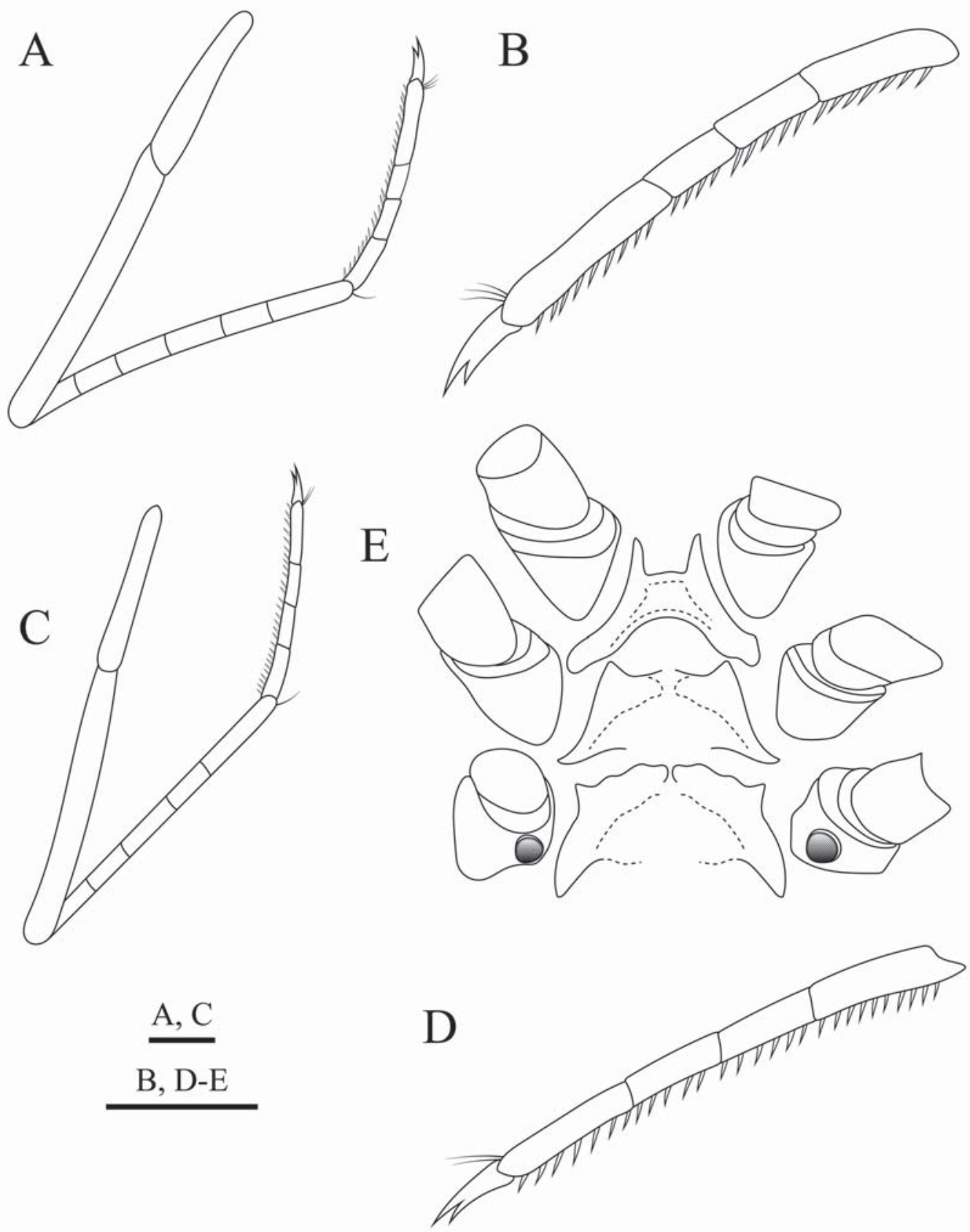

Fig. 6. Odontozona spiridonovi sp.n., Taiwan, holotype, ơ , cl $5.3 \mathrm{~mm}$ (NTOU M02298). A — left fourth pereiopod, lateral view; B same, dactylus and propodus, lateral view; C — left fifth pereiopod, lateral view; D - same, dactylus and propodus, lateral view; E sixth to eight thoracic sternites, ventral view. Scale bars: $1 \mathrm{~mm}$.

Рис. 6. Odontozona spiridonovi sp.n., Тайвань, голотип, О’, cl 5,3 мм (NTOU M02298). А - левая 4-я переопода, вид сбоку; В то же, дактилус и проподус, вид сбоку; С - левая 5-я переопод, вид сбоку; D - то же, дактилус и проподус, вид сбоку; Е - 6-8й грудные стерниты, вид снизу. Масштаб 1 мм.

to fifth pleopods (Figs. 2, 4F) biramous, unarmed, with protopods shorter than both rami.

Telson (Figs 2, 4G) lanceolate, 2 times longer than board; armed with pair of posterolateral spines; dorsal surface bearing 2 longitudinal carinae, each carina armed with 3 strong spines; basal part bearing pair of spines near lateral margin; lateral margin with shallow subproximal concavity and 1 distinct medial spine. Uropods (Figs 2, 4G) well developed; exopod with lateral margin serrated with 6 acute teeth, dorsal surface with 2 unarmed longitudinal carinae, posterior margin rounded; endopod with 2 sharp teeth on lateral margin, posterior margin rounded, dorsal surface with 1 longitudinal carina and 1 intermediate spine between longitudinal carina and lateral margin.

COLORATION. Body generally semitransparent mixed with yellowish brown tan (Fig. 1A, B). Rostrum and cephal- 
Table 2. Branchial formula of Odontozona spiridonovi sp.n. Таблица 2. Жаберная формула Odontozona spiridonovi sp.n.

\begin{tabular}{|c|c|c|c|c|c|c|c|c|}
\hline \multirow[b]{3}{*}{ Pleurobranchs } & \multicolumn{3}{|c|}{ Maxillipeds } & \multicolumn{5}{|c|}{ Pereiopods } \\
\hline & I & II & III & I & II & III & IV & $\mathrm{V}$ \\
\hline & - & - & 1 & 1 & 1 & 1 & 1 & 1 \\
\hline Arthrobranchs & 1 & 1 & 2 & 2 & 2 & 2 & 2 & - \\
\hline Podobranchs & - & 1 & - & - & - & - & - & - \\
\hline Epipods & 1 & 1 & 1 & 1 & 1 & 1 & 1 & - \\
\hline Exopods & 1 & 1 & 1 & - & - & - & - & - \\
\hline
\end{tabular}

ic appendages, anterior and ventral carapace, merus of third pereiopod, abdominal pleura, posterior part of third abdominal somite to sixth abdominal somite, lateral parts of protopods of pleopods covered with dense fine black dots. Cornea darkly pigmented.

SIZE. The single specimen known is the male holotype with a carapace length of $5.3 \mathrm{~mm}$ and body length (excluding rostrum) of $16.2 \mathrm{~mm}$.

ETYMOLOGY. This species is named in honor of Vassily Albertovich Spiridonov for his many contributions to decapod crustacean taxonomy.

DISTRIBUTION. Know only from the southwestern coast of Taiwan, at depths of 116-159 m.

REMARKS. Although the single specimen of this new species has the left antenna, distal parts of the right third maxilliped, right second, third and fifth pereiopods missing (Fig. 1B), it fits well with the characteristics of Odontozona in having the cervical groove with a cincture of spines, the abdomen without dorsal spines, the dactyli of the fourth and fifth pereiopods being biunguiculate [Holthuis, 1993; Goy, 2010].

Members of Odontozona can be separated into two groups according to the abdominal sculpture. The present new species belongs to the group with the abdomen not sculptured (vs. abdomen distinctly sculptured, containing $O$. arbur Saito, Okuno et Anker, 2017, O. edyli Criales et Lemaitre, 2017, O. ensifera (Dana, 1852), O. rubra Wicksten, 1982, O. sculpticaudata Holthuis, 1946 and O. spinosissima Kensley, 1981 [Holthuis, 1993; Goy, 1981, 2015; Kensley, 1981; Wicksten, 1982; Criales, Lemaitre, 2017; Saito et al., 2017). This abdomen non-sculptured group can be further subdivided into two subgroups in terms of the spination on the carapace. Odontozona spiridonovi sp.n. fits into the subgroup with the carapace bearing few, scattered spinules (vs. carapace densely covered with spines, consisting of $O$. addaia Pretus, 1990, O. anaphorae Manning et Chace, 1990, O. fasciata Okuno, 2003, O. foresti Hendrickx, 2002, O. meloi Anker et Tavares, 2013, O. minoica Dounas et Koukouras, 1989, O. okunoi Saito et Fujita, 2018 and O. striata Goy, 1981 [Dounas, Koukouras, 1989; Manning, Chace, 1990; Pretus, 1990; Hendrickx, 2002; Okuno, 2003; Anker, Tavares, 2013; Saito, Fujita, 2018]. Besides, O. spiridonovi sp.n. is unique in the propodus of the third pereiopod being swollen and more than twice as broad as the carpus, and with both the dorsal and ventral margins densely serrated (Fig. $5 \mathrm{D}, \mathrm{E})$, it can be further distinguished from the seven known species of Odontozona with less spinose carapace and nonsculptured abdomen by the following characters.

Odonotozona spongicola (Alcock et Anderson, 1899) can be easily separated from $O$. spiridonovi sp.n. in having the palm of the third pereiopod almost smooth [Holthuis, 1993; Goy, 2010; Chen, Chan, 2021]. The palm of the third pereiopod in $O$. crinoidicola Saito et Fujita, 2009 and $O$. liberta Gore, 1981 has two rows of spines on the dorsal margin and one row of spines on the ventral margin [Gore, 1981; Saito, Fujita, 2009], instead of one row of spines on the dorsal margin and two rows of spines on the ventral margin as in O. spiridonovi sp.n. The cutting edges of the fingers of the third pereiopod are straight in $O$. lopheliae Goy et Cardoso, 2014 [Goy, Cardoso, 2014] but sinuous and crested in $O$. spiridonovi sp.n. (Fig. 5D, E). The Atlantic $O$. edwardsi (Bouvier, 1908) has transverse carinae on the first to third and the sixth abdominal somites [Goy, Cardoso, 2014], whereas only the first and second abdominal somite have transverse carinae in $O$. spiridonovi sp.n. (Fig. 4C, D). Moreover, the ischium of the third pereiopod has four subequal ventral spines in $O$. edwardsi [Goy, Cardoso, 2014] but one large and two small ventral spines in the new species (Fig. 5D, E). For the East Pacific species O. joegoyi Hendrickx et Ayón-Parente, 2014, O. spiridonovi sp.n. differs in bearing two outer teeth on the endopod of the telson (Fig. 4G, vs. unarmed in O. joegoyi, see Hendrickx, Ayón-Parente, 2014: fig. 1E), large antennal spine and three pterygostomial spines (Fig. 4A, B, vs. antennal spine small and eight pterygostomial spines in O. joegoyi [Hendrickx, Ayón-Parente, 2014: fig. 1A], scaphocerite semicircular and about twice as long as broad. (Fig. 4B, vs. lanceolate and about three times as long as broad in O. joegoyi [Hendrickx, Ayón-Parente, 2014: fig 1D].

The remaining species $O$. stigmatica Saito, Okuno et Anker, 2017 from the Ryukyu Islands near Taiwan appears to be most similar to $O$. spiridonovi sp.n. Nevertheless, $O$. spiridonovi sp.n. can be readily distinguished from $O$. stigmatica [Saito et al., 2017] in having more ventral rostral teeth (three in the new species, Fig. 4A vs. one in $O$. stigmatica), the third maxilliped with the merus bearing two spines and the ischium unarmed (Fig. 5A, vs. merus with seven spines and ischium with row of spines in O. stigmati$c a$ ), propodus and carpus subdivided into less articles in the fourth and fifth pereiopods (4 in propodus and 5-6 in carpus for $O$. spiridonovi sp.n., Fig. 6A-D vs. 5 in propodus and 78 in carpus for $O$. stigmatica). The palm of the third pereiopod is subcylindrical, only 1.4 times as broad as the carpus and has the spines on the dorsal and ventral margins widely spaced in O. stigmatica. Moreoever, O. stigmatica inhabits very shallow water ( $5 \mathrm{~m}$ deep) and has the body covered with many thin reddish stripes [Saito et al., 2017].

Acknowledgements. This work was supported by grants from the Ministry of Science and Technology, Taiwan, R.O.C. and the Center of Excellence for the Oceans (National Taiwan Ocean University), which is financially supported by The Featured Areas Research Center Program within the framework of the Higher Education Sprout Project by the Ministry of Education (MOE) in Taiwan, R.O.C. 


\section{References}

Alcock A. 1901. A descriptive catalogue of the Indian deep-sea Crustacea Decapoda Macrura and Anomala, in the Indian Museum. Being a revised account of the deep-sea species collected by the Royal Indian Marine Survey Ship Investigator. Calcutta: The Trustees of the Indian Museum. 286 p.

Alcock A., Anderson A.R.S. 1899. Natural History Notes from H.M. Royal Indian Marine Survey Ship 'Investigator,' Commander T.H. Heming, R.N., commanding. Series III. No.2. An Account of the Deep-sea Crustacea dredged during the Surveying - season of 1897-98 // The Annals and Magazine of Natural History. Ser.7. Vol.3. P.1-27, 278-292.

Anker A., Tavares M. 2013. Description of a new deep-water stenopodid shrimp of the genus Odontozona Holthuis, 1946 (Crustacea, Decapoda) from Brazil // Marine Biology Research. Vol.9. P.421-430.

Bouvier E.-L. 1908. Sur les relations zoologiques des Crevettes de la tribu des Sténopidés // Comptes rendus hebdomadaires des séances de 1'Académie des sciences. Vol.146. P.887-891.

Chen C.-L., Chan T.-Y. 2021. First record of the rare stenopodidean shrimp Odontozona spongicola (Alcock \& Anderson, 1899) (Decapoda: Stenopodidea: Stenopodidae) from Indonesia // Zootaxa. Vol.4915. P.575-584.

Chevaldonné P., Pretus J.L. 2021. Rediscovery of the rare Mediterranean marine cave stenopodid shrimp Odontozona addaia Pretus, 1990, 30 years after its original description (Crustacea: Decapoda: Stenopodidea) // Zootaxa. Vol.4950. P.137-148.

Criales M.M. 1997. Microprosthema granatense, new species, from the southern Caribbean, with a key to shrimps of the genus Microprosthema from the western Atlantic and a new record of Odontozona libertae (Decapoda: Stenopodidea) // Journal of Crustacean Biology. Vol.17. P.538-545.

Criales M.M., Lemaitre R. 2017. A new species of Odontozona Holthuis, 1946 (Crustacea: Decapoda: Stenopodidea: Stenopodidae) from the Caribbean Sea // Zootaxa. Vol.4276. P.405415 .

Dana J.D. 1852. Conspectus Crustaceorum quae in Orbis Terrarum circumnavigatione, Carolo Wilkes e Classe Republicae Foederatae Duce, lexit et descripsit. // Proceedings of the Academy of Natural Sciences of Philadelphia. Vol.6. P.10-28.

De Grave S., Anker A. 2017. An annotated checklist of marine caridean and stenopodidean shrimps (Malacostraca: Decapoda) of the Caribbean coast of Panama // Nauplius. Vol.25. P.140 .

De Grave S., Fransen C.H.J.M. 2011. Carideorum catalogus: the recent species of the dendrobranchiate, stenopodidean, procarididean and caridean shrimps (Crustacea: Decapoda) // Zoologische Mededelingen, Leiden. Vol.85. P.195-589.

Dounas C., Koukouras A. 1989. Odontozona minoica, new species, from the Eastern Mediterranean Sea (Decapoda: Stenopodidea) // Journal of Crustacean Biology. Vol.9. P.341-348.

Gore R.H. 1981. Three new shrimps, and some interesting new records of decapod Crustacea from a deep-water coral reef in the Florida Keys // Proceedings of the Biological Society of Washington. Vol.94. P.135-162.

Goy J.W. 1981. Studies on West Indian Stenopodidae: 1. Odontozona striata new species from off the western coast of Cuba (Crustacea: Decapoda: Stenopodidea) // Bulletin of Marine Science. Vol.31. P.843-852.

Goy J.W. 1992. Systematics and zoogeography of Eastern Pacific stenopodidean shrimps (Crustacea: Decapoda) // Proceedings of the San Diego Society of Natural History. Vol.22. P.1-6.

Goy J.W. 2010. Infraorder Stenopodidea Claus, 1872 // Schram F.R. et al. (eds.). Treatise on Zoology - Anatomy, Taxonomy, Biology. The Crustacea, Decapoda. Vol.9. Part A. Eucarida:
Euphausiacea, Amphionidacea, and Decapoda (partim). Leiden: Brill. P.215-265.

Goy J.W. 2015. Stenopodidean shrimps (Crustacea: Decapoda) from New Caledonian waters // Zootaxa. Vol.4044. P.301344.

Goy J.W., Cardoso I.A. 2014. Redescription of Odontozona edwardsi (Bouvier, 1908) (Decapoda: Stenopodidea: Stenopodidae) and description of a new species of Odontozona commensal on the deep-water coral, Lophelia pertusa (Linneaus, 1758) // Zootaxa. Vol.3774. P.552-566.

Hendrickx M.E. 2002. A New Deep Water Species of Odontozona Holthuis (Decapoda, Stenopodidae) from the Southern Gulf of California, Mexico // Crustaceana. Vol.75. P.405-412.

Hendrickx M.E., Ayón-Parente M. 2014. A new deep-water species of Odontozona (Decapoda: Stenopodidea: Stenopodidae) from the East Pacific, and new record of $O$. foresti Hendrickx, 2002 // Zootaxa. Vol.3835. P.338-348.

Herrera R., Moro L., Martin J., Ocaña O., Bacallado J.J., Ortea J. 2016. Primeros registros de invertebrados marinos para las islas Canarias // Revista de la Academia Canaria de Ciencias. Vol.28. P.231-242.

Holthuis L.B. 1946. Biological results of the Snellius Expedition. XIV. The Decapoda Macrura of the Snellius Expedition. I. The Stenopodidae, Nephropsidae, Scyllaridae and Palinuridae // Temminckia. Vol.7. P.1-178.

Holthuis L.B. 1993. The recent genera of the caridean and stenopodidean shrimps (Crustacea, Decapoda): with an appendix on the order Amphionidacea. Leiden: Nationaal Natuurhistorisch Museum. 328 p.

Kensley B. 1981. The South African Museum's Meiring Naude cruises. Part 12. Crustacea Decapoda of the 1977, 1978, 1979 cruises // Annals of the South African Museum. Vol.83. P.4978 .

Koukouras A., Dounas C. 2000. Decapod Crustaceans New to the Fauna of the Aegean Sea // Crustaceana. Vol.73. P.497-502.

Lee S.H. 2020. First record of Odontozona arbur (Decapoda: Stenopodidae: Odontozona) from Korea // Journal of Species Research. Vol.9. P.247-250.

Manning R.B., Chace F.A., Jr. 1990. Decapod and stomatopod Crustacea from Ascension Island, South Atlantic Ocean // Smithsonian Contributions to Zoology. Vol.503. P.1-91.

Okuno J. 2003. A new species of the genus Odontozona Holthuis, 1946 (Crustacea: Decapoda: Stenopodidae) from submarine caves in southern Japan // Natural History Research. Vol.7. P.167-180.

Pretus J.L. 1990. Description of Odontozona addaia spec. nov. (Crustacea: Decapoda: Stenopodidae) from a marine cave in the island of Minorca, western Mediterranean // Zoologische Mededelingen, Leiden. Vol.63. P.343-357.

Saito T., Fujita Y. 2009. A new species of the genus Odontozona (Decapoda: Stenopodidea: Stenopodidae) associated with a comatulid crinoid from the Ryukyu Islands // Bulletin of the National Museum of Nature and Science. Series A (Zoology). Suppl. Vol.3. P.123-135.

Saito T., Fujita Y. 2018. A new species of the stenopodidean shrimp genus Odontozona Holthuis, 1946 (Crustacea: Decapoda: Stenopodidea: Stenopodidae) from the Ryukyu Islands, Indo - West Pacific // Zootaxa. Vol.4450. P.458-472.

Saito T., Okuno J., Anker A. 2017. Two new species of the stenopodidean shrimp genus Odontozona Holthuis, 1946 (Decapoda: Stenopodidae) from the Indo - West Pacific // Crustacean Research. Vol.46. P.25-55.

Wicksten M.K. 1982. Two species of Odontozona (Decapoda: Stenopodidea) from the Eastern Pacific // Journal of Crustacean Biology. Vol.2. P.130-135.

Responsible editor I.N. Marin 